\title{
Geotechnical design and uncertainty in residual soil slopes
}

\author{
KT Mandisodza Evolution Mining Ltd, Australia \\ MJ Dunn Evolution Mining Ltd, Australia
}

\begin{abstract}
Mining in residual soils is a characteristic of some open pit mines, particularly those mines in the tropical and sub-tropical regions. With residual soils' prevalence on the earth's surface almost as common as that of sedimentary rocks (Wesley 2013), mining in such soils requires special understanding of the behaviour and characteristics of the residual soil to determine slope designs that are both safe and economic. Due to the presence of relict structures, and the relatively low strength of the residual soils and weathered rock, design slope angles in these materials should be developed by blending the results of the kinematic assessments of geologic structures with rock mass stability analyses and traditional soil mechanics (Newcomen \& Burton 2000). It is thus imperative that geotechnical designs should be site/location-specific and based on soil's field performance, back-analyses and risk zoning. Understanding the variability of these materials is important for developing robust designs. This paper outlines the different aspects that are to be considered when conducting slope designs in residual soils, and in particular, saprolites, and summarises shear strength data from various mine sites that highlights the uncertainty associated with these parameters.
\end{abstract}

Keywords: saprolite, residual soils, slope design, uncertainty, variability, reliability

\section{Introduction}

What is a residual soil? There are several definitions around the term 'residual soil', proposed by different authors over the years. Generally, a residual soil is a soil which has been formed in situ by the decomposition of the parent material and which has not been transported any significant distance. Below are some of the definitions that have been proposed over the years:

- A residual soil is the product of rock weathering that remains in place above the yet-to-be weathered parent rock (Sowers 1985).

- A residual soil is material with a soil-like consistency that is located below the local ancient surface (i.e. below the pebble marker (Blight 1985)).

- A soil formed by weathering in place, but with the original rock texture completely destroyed; a definition commonly used in a wider sense to include highly to completely decomposed rock which is an engineering material that behaves like a soil (Brand \& Phillipson 1985).

- Residual soils are those that form from rock or accumulation of organic material and remain at the place where they were formed (McCarthy 1993).

- Entire unconsolidated superficial cover is referred to as a soil (Press \& Siever 1994).

- This mantle is also termed the regolith, which is separated into the upper part referred to as a soil, and the portion below it and above the bedrock, called saprolite (Bland \& Rolls 1998).

Blight (1997), defines three sub-categories of residual soils as saprolites, laterites and mature soils. Saprolites are defined as having soil-like strength and consistency, and retain recognisable relicts of the structure and fabric of the parent rock. These relict structures constitute planes of weakness and zones of higher permeability. Saprolite also refers to that part of the weathering profile where the soil largely preserves the microfabric and volume of its parent rock (Aydin et al. 2000). 
Laterites are defined as highly altered residual soils that have had silica leached out and have some degree of cementation by sesquioxides, giving a nodular appearance. The laterites are defined to be typically rich in hematite and boehmite and their high iron content gives them a deep reddish colour. They tend to occur near the surface and extent to limited depths.

Mature soils are those soils that have undergone physical and chemical weathering to the extent that no evidence of the parent rock's fabric or structures remain.

Residual soils can be found throughout the world but primarily in the tropics (Newcomen et al. 2000) and are as common as sedimentary rocks (Wesley 2013), as shown in Figure 1.

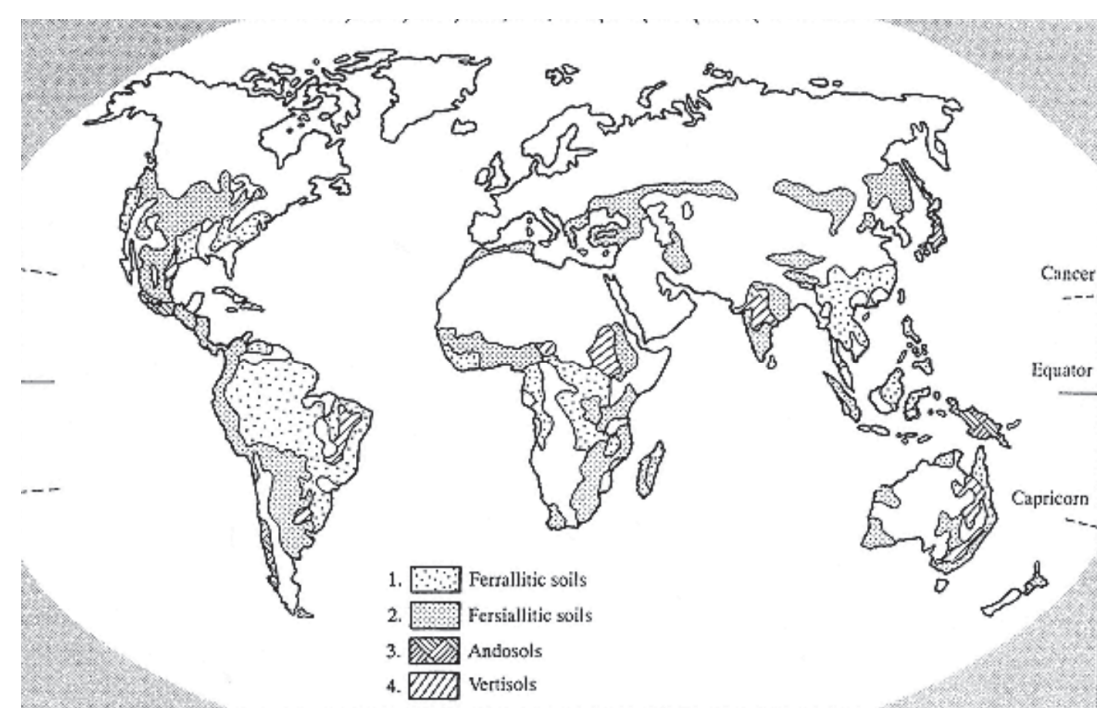

Figure 1 Simplified world distribution of the principle types of tropical residual soil (based on Food and Agriculture Organization World Soil Map) (Bell 2000)

This paper is an overview of geotechnical slope design in residual soils, particularly saprolites and aspects that are considered in the design of saprolite slopes. The paper will also discuss uncertainty and the impact this can have on slope design reliability, and provide a summary of shear strength parameters from several mines and relate these to target confidence levels for geotechnical models.

\section{Aspects to consider for slope design in residual soils}

\subsection{Residual soil mineralogical composition and engineering significance}

The mineralogy of residual soils has engineering significance in the aggregation and cementation of soils (Burton 1998). Mineralogy can have effect on index properties such as, moisture content, density testing and Atterberg limits. Weathering-induced changes in joint properties are mineralogical, due to wall alteration.

Mineralogical properties of residual soils tend to have a wide variation range; so does grain size and unit weight, since they are 'transitional' between parent rock characteristics and effects of weathering processes. Coarser grains in the residual soils normally are inherited from the parent rock and may consist of unweathered quartz or partially weathered feldspar, the latter which is likely to degrade during shear (Bell 2000). Stability reaction of the soils will vary from mineral to mineral constituents within the soils (i.e. quartz is more stable than feldspar).

Relict jointing and bedding, as well as the development of fissures, affect the behaviour of residual soil. Low strength along relict discontinuities may be attributable to particles being coated with low-friction iron/manganese organic compounds. Angles of shearing resistance along such surfaces may be around $15-20^{\circ}$, falling to around $10^{\circ}$ when they are slickensided (The Geological Society 1990). 
Kaolinites that form because of chemical weathering, can form many species within the residual soil and can show different crystallinity which equally control the mineral stability within the soil (Schellmann 2008); hence residual soil containing kaolinite has higher strength and a lower compressibility than one with a similar clay fraction containing smectite (Bell 2000).

According to Horn and Deere (1962), kaolinite is a layer lattice mineral that, when saturated, has a basic friction angle which is reduced greatly due to the lubricating action of water ( $\tan \phi_{\text {sat }}^{\prime} / \tan \phi^{\prime}$ dry $=0.4$ to 0.6 ). Further chemical and mineralogical changes through weathering may occur within short periods of time along discontinuities planes and within the soil matrix itself (i.e. changes of mineralogy in a halloysite-rich volcanic saprolite contributed to the creeping of the surface material and formation of shear surface at a landslide in Hong Kong (Irfan 1994)).

\subsection{The role of structural controls in residual soils}

The role of relict structures in the stability of residual soils, particularly the saprolites, is quite significant. The significance of relict structures in saprolites is due to preservation of the microfabric and volume of the parent rock (Aydin et al. 2000). According to a statistic by Irfan and Woods (1988), they state that many of the landslides which occur in the saprolitic soil zone are directly or indirectly controlled by relict structures or discontinuities. Several other authors who have alluded to the role of relict structures in slope failures (St John et al. 1969; Vargas \& Pichler 1957; Massad \& Teixeira 1985; Costa \& Fernandes 1985; Crowland \& Carbray 1988; Chigira 2001; Wen \& Aydin 2003).

Because of a smearing effect when saprolitic soils are excavated during site investigations and/or mining activities, it becomes very difficult and cumbersome to clearly delineate the extents of structural networks in saprolitic soils. This notion has been identified as an attribute to landslide occurrences (Irfan 1998). The inadequacy of attention to structural features during site investigations and construction leads to application of inappropriate methods of analysis for design.

Besides the role of relict structures within a saprolitic soil, there are other sources of heterogeneities that might be prevalent in residual soils (i.e. microfabric and mineralogical variations and macro-structural features such as secondary clay seams, relatively less weathered rock slabs, irregular zones of contrasting weathering, differential weathered dykes, corestones and soil pipes at a field scale (Aydin \& Duzgoren-Aydin 2002)). The large variability of the heterogeneities implies that some critical features that might have a greater effect on stability might be misrepresented during data collection or might totally be omitted in the stability analyses. According to Hencher et al. (1984), the importance of the heterogenous nature of saprolitic slopes is that some steep slopes which had been predicted to be unstable remained standing, while others that had been predicted to be stable collapsed or underwent large or progressive deformation, thus being consistent with the unpredictable nature of saprolitic soils with heterogeneities in slope designing.

This unpredictability of strength parameters due to variability over short distances in saprolitic soils requires that more representative strength parameters be determined through back-analyses of slope failures or the use of empirical designs based on local site-specific experiences. Variability of scales should be reduced from tens of metres to scales of 1 to $2 \mathrm{~m}$, and finally, to tens of centimetres within representative samples (De Mello 1972). By this reduction, the problem of multilevel complex heterogeneities in ground investigations is reduced (Aydin et al. 2000). However, Hencher and McNicholl (1995) pointed out the difficulties that surround accurate predictions of geotechnical conditions, despite careful investigations, and that variability cannot usually be determined from extrapolation or interpolation. 
Stability effects of corestones in residual soils have been extensively studied by Lindquist and Goodman (1994), West et al. (1991), and Hencher and Martin (1982). Corestones are defined as a chaotic occurrence of large particles (boulders and cobbles) in a matrix of considerably smaller particles (sand and silt) which is typical of saprolites and developed over widely to moderately jointed igneous and metamorphic rocks (Aydin et al. 2000). West et al. (1991) concluded that, depending on the relative strength of larger particles, three types of failure surfaces were suggested:

1. Involving intra-block fractures (weak large blocks).

2. Through block-matrix contacts (strong block, low stress allowing dilation).

3. Formation of wide shear zones due to block interaction:

a. Provided the blocks are not too large with respect to slope,

b. the soil is not strongly bimodal,

c. large particles content $>25-30 \%$, or

d. there is high stress supressing dilation.

Figure 2 shows the influence of large particles on a failure surface, highlighting the three types of failure discussed above. According to Aydin et al. (2000), the effects of large particles on stability of slopes discussed above, do not account for position and distribution of other features such as small relict discontinuities around which slip zones may initiate and propagate. Also, the relative position and orientation of corestones with respect to the slope toe may significantly influence the critical local stress concentration and possibly the thickness and geometry of the potential slip zone.

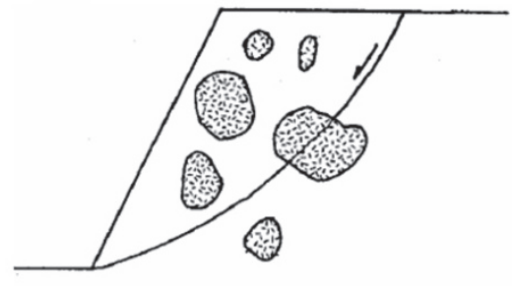

(a)

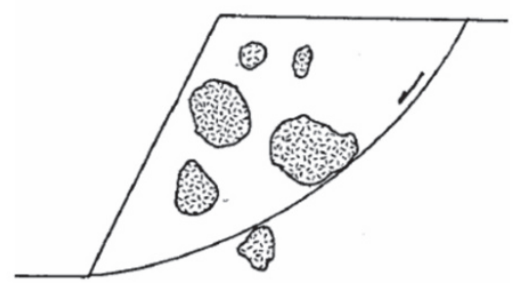

(b)

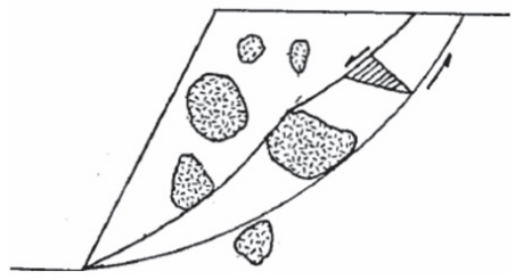

(c)

Figure 2 Influence of large particles on the failure surface: (a) Involving intra-block structure; (b) Through block-matrix contacts; (c) Forming a wide shear zone (West et al. 1991) 
Figure 3(a) shows the smearing effect during the excavation process, making it difficult to visualise structural controls and to measure them. Figure 3(b) shows emergent corestones in a lateritic matrix.

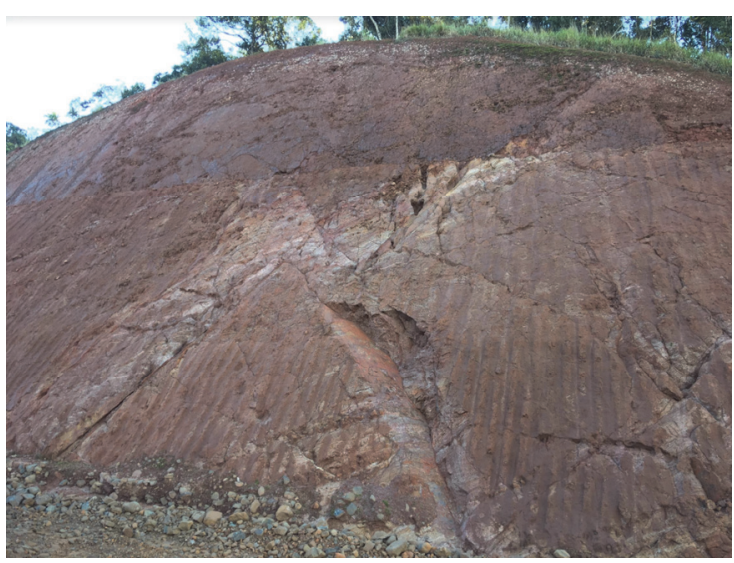

(a)

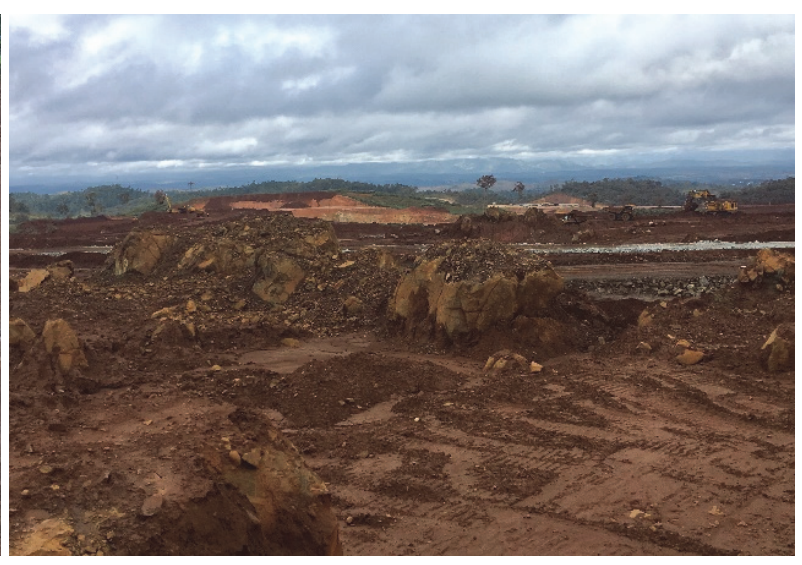

(b)

Figure 3 (a) Typical relict structural controls in an igneous rock saprolite; (b) Emergent corestones in an open pit floor (Madagascar). Slopes cut within the lateritic matrix hosting the corestones will be significantly compromised on strength and performance due to the presence of the heterogeneities imposed by the corestones as discussed previously

\subsection{Hydrological conditions and residual soils}

Surface and sub-surface hydrological patterns play a major role in the behaviour and characteristics of residual soil's integrity and stability as they tend to manipulate the principle engineering aspects that govern stability (i.e. shear strength, compressibility, consolidation and permeability). It is from this deduction that many slope failures in tropical regions, typically characterised by residual soils, are attributed to complex hydrological conditions.

According to Aydin (2006), abnormal flow patterns, fast build-up and/or chaotic distribution of porewater pressure are the most common causative factors of landslides. The interaction of hydrological conditions and flow patterns within paleo-structures has a significant effect on the engineering properties of residual soils. According to Aydin et al. (2000), asymmetric responses of saturation-dissipation cycles can be attributed to relict structures that are interconnected or open to surface infiltration paths but terminate at low permeability boundaries. The resultant prolonged state of saturation leads to a loss of cohesion (relict bonding) and collapse of material.

The statement by Aydin alludes to that of Hencher et al. (1984), that many failures can be attributed to complex hydrological conditions that cannot be accounted for in stability analysis. Relict joints and corestones-matrix boundaries may act as preferential seepage paths sometimes resulting in high inflow rates leading to internal erosion and soil pipes (Brand et al. 1986).

Residual soils are usually characterised by high-permeability patterns caused by various factors including their relatively coarse nature, presence of unusual clay minerals, and forms of micro-structures (Wesley 2013). These high-permeability patterns make the residual soils susceptible to rapid changes in material properties when subjected to changes in external hydraulic patterns (Aydin et al. 2000).

A good summary of the behaviour of cut slopes in residual soils to intense prolonged rainfall, which is a main trigger for slips and landslides in such slopes, was done by Wesley (2013), who attributed such instabilities to high-permeability patterns that are characteristic of residual soils. Wesley, compared the permeability of residual soils to that of sedimentary rocks, and his concluding remark was that water tables in residual soils may be relatively steep. 
Figure 4 shows the short and long-term stability of residual slopes, and variation of pore pressure, effective stress and Factor of Safety (FS) relative to cyclical variations of seasons (time). Understanding of the hydrologic behaviour of residual soils slopes under different climatic conditions can provide mitigatory strategies against rainfall-induced slope failures (Rezaur et al. 2003).

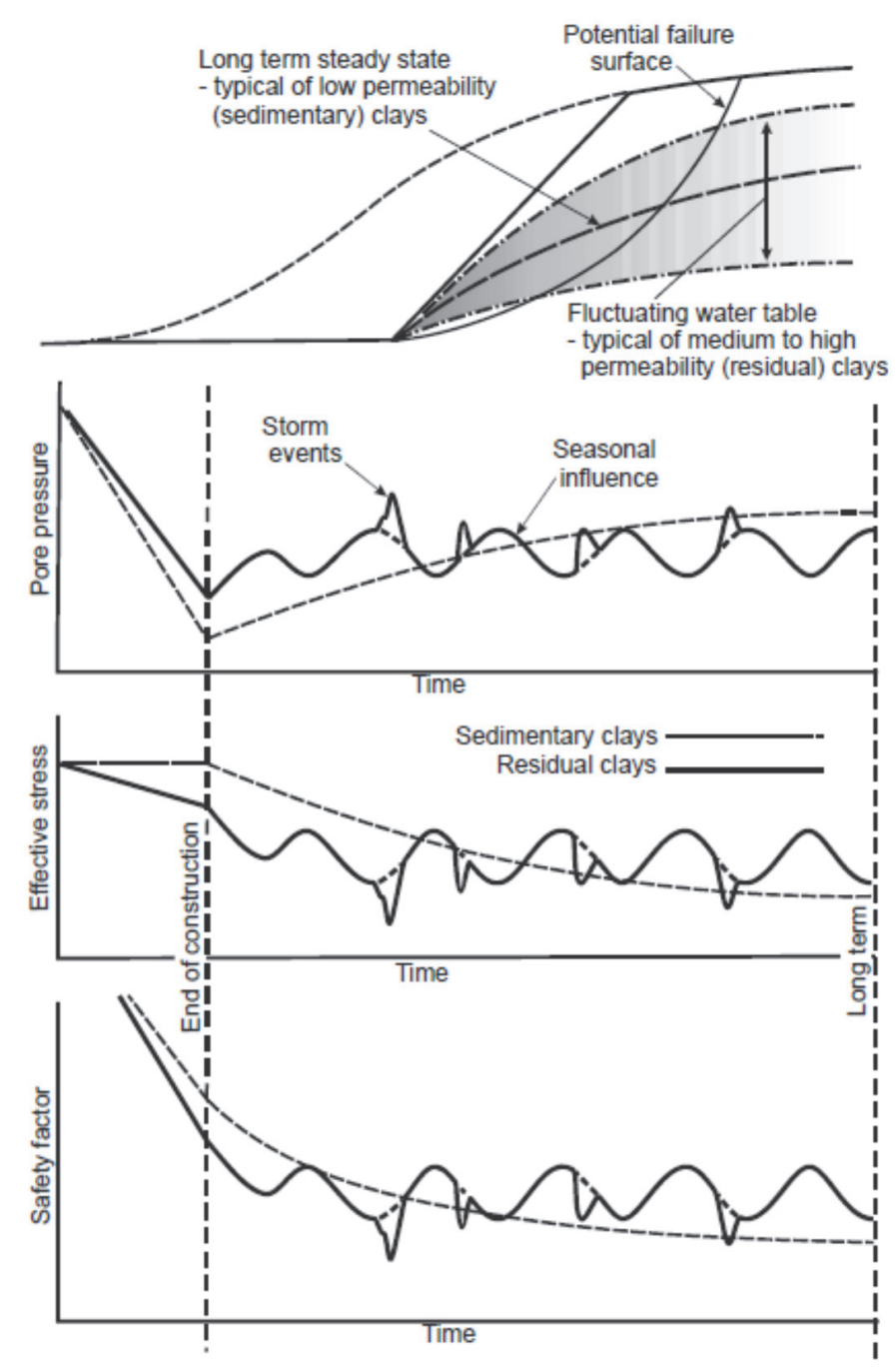

Figure 4 Short and long-term stability of slopes in residual soils and sedimentary rocks (after Wesley 2010a)

Slope failures in residual soils have been linked to both the intensity and duration of rainfall events, and have been shown to occur as a result of dissipation of the negative pore pressure in the slope as a result of infiltration (Fredlund \& Rahardjo 1994). Failure is often rapid and occurs sometime after rainfall commences, and in some instances, after the rainfall ceases or diminishes (Lumb 1975; Brand 1984; Patton \& Deere 1971; Vargas et al. 1986).

\subsection{Shear strength of residual soils}

Generally, the factors influencing the strength and behaviour of tropical residual soil are inter-particle bonding, relict structures and discontinuities, anisotropy, partial saturation, and lastly, void ratio (Blight 1997).

Selection of appropriate shear strength (saturated/unsaturated) parameters is critical in the evaluation and design of residual slopes. Residual soils like many of the other soil formations are usually characterised by saturated and unsaturated soil conditions. According to Fredlund and Rahardjo (1993), soils that are unsaturated form a large category of materials which do not adhere in behaviour to classical, saturated soil mechanics. 
Residual soils are often unsaturated (or approaching saturation) in nature, and the porewater pressures are negative relative to atmospheric conditions (Rahardjo et al. 1995). Matric suction has been attributed to be the main contributor towards the stability of natural slopes in residual soils (Fredlund \& Rahardjo 1985).

The shear strength theory of an unsaturated soil takes the form of an extended Mohr-Coulomb envelope (Fredlund et al. 1978), which can be used to evaluate the contribution of the matric suction on the shear strength (Rahardjo et al. 1995). The shear strength equation for unsaturated soils is:

$$
\tau_{\mathrm{ff}}=\mathrm{c}^{\prime}+\left(\sigma_{\mathrm{f}}-\mathrm{u}_{\mathrm{a}}\right)_{\mathrm{f}} \tan \phi^{\prime}+\left(\mathrm{u}_{\mathrm{a}}+\mathrm{u}_{\mathrm{w}}\right)_{\mathrm{f}} \tan \phi^{\mathrm{b}}
$$

where:

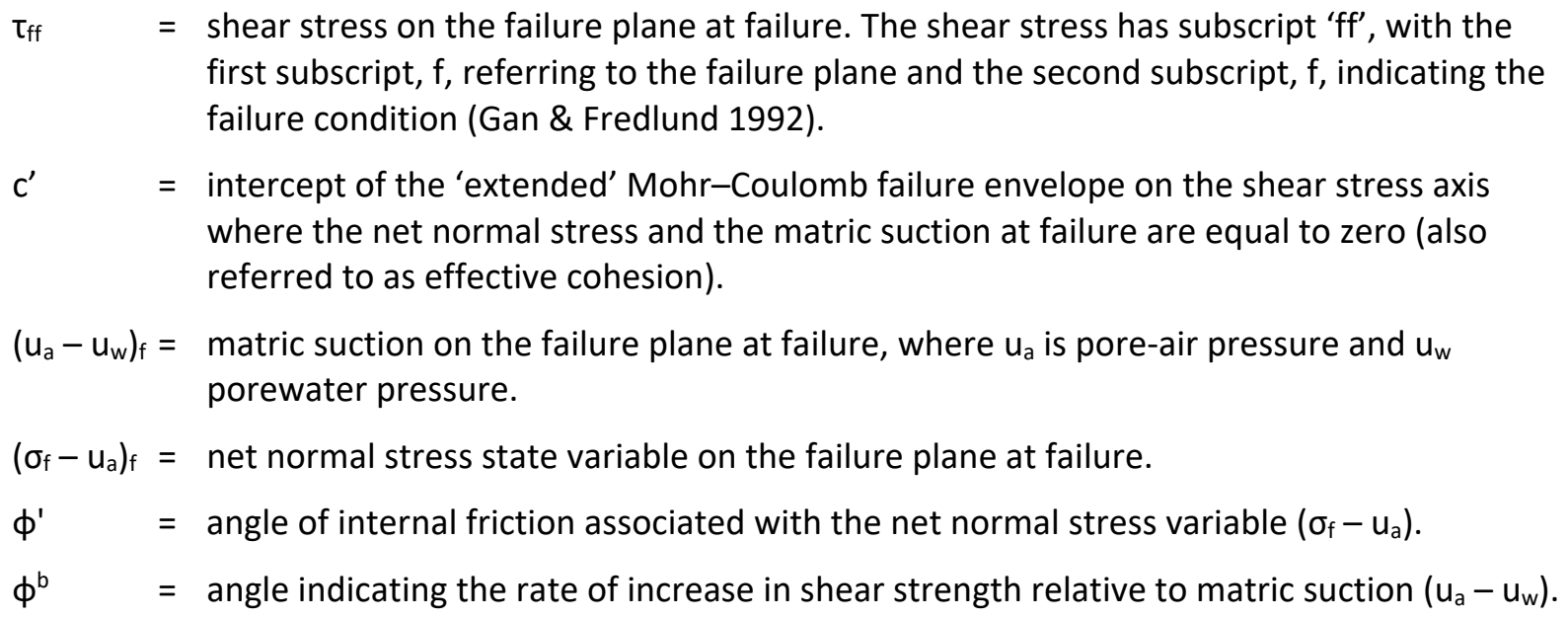

Equation 1 defines a planar failure envelope surface (Rahardjo et al. 1995), as shown in Figure 5, though other authors have proposed non-linearity in the shear strength versus matric suction relationship (e.g. Satija 1978; Escario \& Saez 1986; Gan \& Fredlund 1988; Drumright 1989; Toll 1990).

Figure 5 shows a planar failure envelope for a saturated condition where the matric suction is zero. The effective angle of internal friction is the same for all suction values since the failure envelope is assumed to have no 'warp' (Fredlund \& Rahardjo 1994).

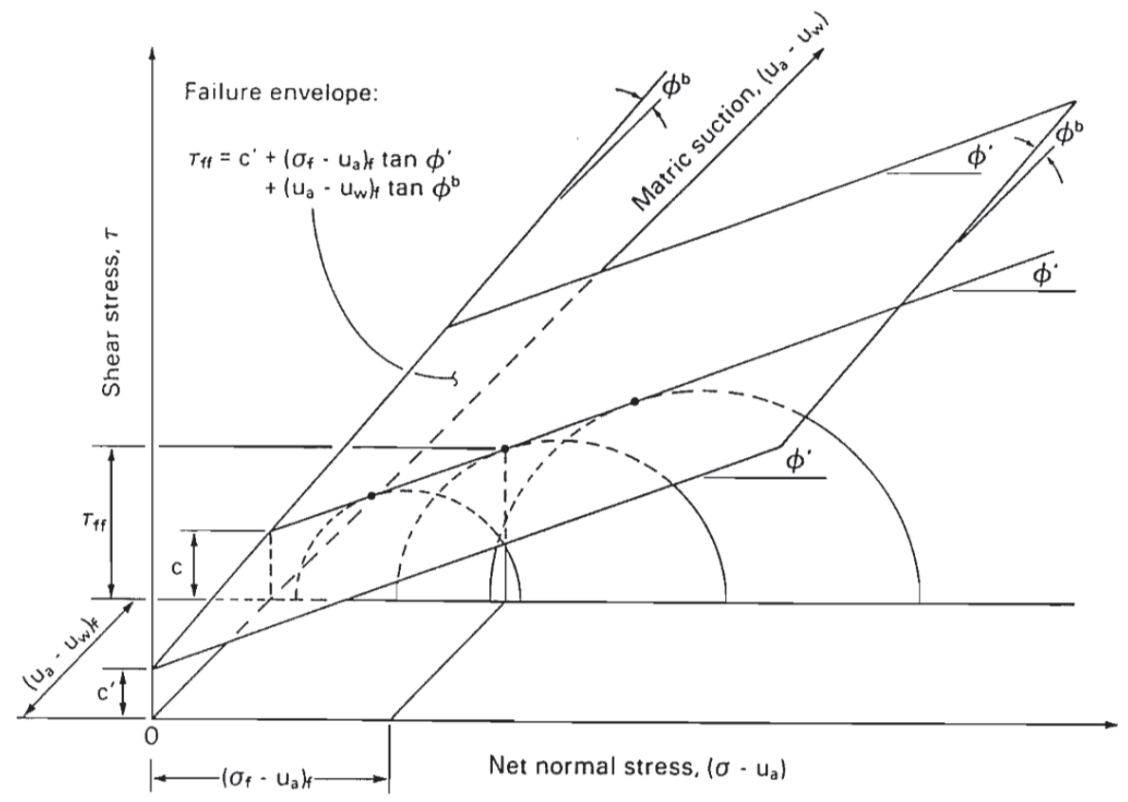

Figure 5 Extended Mohr-Coulomb failure envelope for soils with matric suction (adopted from Rahardjo et al. 1995) 
The shear strength equation for an unsaturated soil can be viewed as an extension of shear strength equation for a saturated soil. For an unsaturated soil, two stress state variables are used to describe its shear strength, while only one stress state variable (i.e. effective normal stress $\sigma_{f}-u_{w f}$ ) is required for a saturated soil (Gan \& Fredlund 1992).

The shear strength of a saturated soil is commonly described using the Mohr-Coulomb failure criterion and the effective stress concept (Terzaghi 1936).

$$
\tau_{\mathrm{ff}}=\mathrm{c}^{\prime}+\left(\sigma_{\mathrm{f}}-\mathrm{u}_{\mathrm{w}}\right)_{\mathrm{f}} \tan \phi^{\prime}
$$

where:

$$
\begin{aligned}
& \mathrm{\tau}_{\mathrm{ff}}=\text { shear stress on the failure plane at failure. } \\
& c^{\prime}=\text { shear strength intercept on the shear stress axis when the effective normal stress is } \\
& \text { zero. Also referred to as 'effective cohesion'. } \\
& \left(\sigma_{f}-u_{w}\right)_{f}=\text { effective normal stress on the failure plane at failure. } \\
& \sigma_{\mathrm{ff}} \quad=\text { total normal stress on the failure plane at failure. } \\
& \mathrm{u}_{\mathrm{wf}}=\text { porewater pressure at failure. } \\
& \phi^{\prime}=\text { effective angle of internal friction. }
\end{aligned}
$$

Equation 2 defines a line which is commonly referred to as a failure envelope. The envelope represents possible combinations of shear stress and the effective normal stress on the failure plane at failure.

According to Gan and Fredlund (1992), the extreme variability in the shear strength is likely due to the importance of the initial soil structure of the soil. In saprolitic soils, the structure of the soil is, amongst other factors, also strongly affected by the microfabric of the soils. The microfabric is a function of the nature and intensity of the weathering process (Massey et al. 1989).

From the preceding paragraphs, the effects of matric suction on the stability of slopes, particularly those slopes cut in residual soils, have been extensively documented by various authors who, more or less, converged on the same conclusions regarding matric suction and stability of slopes. Hence, slope designs in residual soils should adopt similar principles, determination of the matric suction and its effects in the calculation of the strength properties of the soil and derivation of practical safety factors for slopes. Studies by Ching et al. (1984) have indicated that soil suction plays a significant role in increasing the FS for slopes.

From these studies, different stability models have been developed to include the effects of soil suction on the stability of slopes. Griffith and Lu (2005) developed the Lu and Likos (2004) model, which estimated the effects of soil suction on the stability of slopes rather than altering the shear strength of the soil as presented by Fredlund et al. (1978). The equation by Lu and Likos (2004) unified saturated and unsaturated conditions, to estimate the effects of soil suction on the effective stress of the soil. Other models have been proposed by Lu and Godt (2008), Anderson and Lloyd (1991), and Wilkinson et al. (2002).

\subsection{Typical slope failures in residual soils}

Slope failures in residual soils have been linked to both intensity and duration of rainfall events, and have been shown to occur as a result of dissipation of the negative pore pressure in the slope as a result of infiltration (Fredlund \& Rahardjo 1994). Failure is often rapid and occurs sometime after rainfall commences, and in some instances, after the rainfall ceases or diminishes (Deere \& Patton 1971; Lumb 1975; Brand 1984). Surface and sub-surface water management around pit slopes hence becomes critical in order to regulate surface flow around the pit crest and to minimise rate of infiltration, especially from ponded water. Reducing residency time for water sitting on catchment berms also allows for delayed dissipation of negative pore pressure, enhancing the stability of the slopes. 
According to Wesley (2011), slope failures in residual soils are unlikely to be deep-seated circular failures, especially when steep slopes are involved, they are likely to be relatively shallow, with fairly planar failure surfaces. Failures in residual soils, particularly saprolites, are mainly controlled by relict structures and intact weathered material. According to Irfan (1998), the main failures involving relict structures can be grouped under the following headings:

- Translational failures with shear surfaces defined entirely or partially by relict structures (planar, wedge or a combination of types).

- Toppling and mass toppling.

- Circular and non-linear failures.

- (Progressive) mass creep and complex failures.

Generally, failures along prominent structures are rapid and very common to occur during or after heavy rainfall. For residual soils (weathered rock mass), conventional limiting equilibrium methods of stability analysis become inappropriate for progressive failures, as they do not take account of stress distribution within a slope (Irfan 1998).

\section{$3 \quad$ Uncertainty in residual soil slope design}

Lupo et al. (2015) recommends a slope design process for residual soils, and this approach is supported by the authors. However, this approach can be enhanced by further consideration of uncertainty in the design process. As with any slope design, it is important to develop a reliable slope design that satisfies industry acceptance, such as FS and probability of failure (PF). To do this, it is necessary to develop design inputs that are at an appropriate confidence level or reliability to support the study stage or final design (i.e. inputs need to be commensurate with the required design reliability). This requires the development of the suitable geotechnical model at the required confidence level and the derivation of appropriate material property inputs.

The term 'uncertainty' is loosely applied in geotechnical engineering and can broadly be divided into natural uncertainty (randomness) and uncertainty related to human nature (lack of knowledge and understanding). A discussion of various types of uncertainty can be found in Dunn $(2014,2015)$. When dealing with geotechnical uncertainty it is common to refer to data confidence or data reliability and these terms are often used interchangeably when discussing geotechnical data and models, which can be confusing.

Confidence can be expressed as a level or an interval. A confidence level refers to the percentage of all possible samples that can be expected to include the true population parameter. Statisticians use a confidence level to describe uncertainty associated with the interval estimate.

A confidence interval is used to express the degree of uncertainty associated with a sample statistic. A confidence interval is an interval estimate combined with a probability statement. Confidence intervals are preferred to point estimates, and to interval estimates, because only confidence intervals indicate (a) the precision of the estimate and (b) the uncertainty of the estimate. Reliability is a statement of error or precision of an estimate. Data reliability is a state that exists when data is sufficiently complete and error free to be convincing for its purpose and context.

Uncertainty has a direct impact on the data confidence and reliability, and thus has a direct impact on the design reliability. This would typically be due to increased PF for a given FS (i.e. a large spread in input data will result in a wider spread around the mean FS and increase proportion of values FS $<1(P F))$. The higher the PF, the lower the design reliability.

The following sections briefly discuss geotechnical uncertainty in the context of slope design in residual soils, and include an overview of the geotechnical model and an attempt to quantify uncertainty associated with shear strength parameters. The data used to demonstrate geotechnical uncertainty is from various saprolite slope design studies. 


\subsection{Geotechnical model}

The geotechnical model is the basis of any geotechnical design and this model needs to be at a confidence level commensurate with the required design reliability. The requirements for a geotechnical model used in slope design are described in detail by Read and Stacey (2009). The geotechnical model comprises several components, as follows:

- Geological model.

- Structural model.

- Hydrogeological model.

- Rock/soil mass model.

Geotechnical domains are then derived from the geotechnical for use in defining slope design sectors.

There are various uncertainties associated with development of geotechnical models, and these are described by Dunn $(2014,2015)$. Generally, the quality and confidence level of the geotechnical model improves over time as the project advances through early study to operational stages. Read (2009) defines target confidence levels for the various components of the geotechnical model at various stages in the project life.

The collection of rock/soil mass data for saprolites can be challenging as these materials bridge the soil to weak rock mass transition zone. Conventional rock mass classification systems, such as rock mass rating (Bieniawski 1989) or geological strength index (Marinos \& Hoek 2000), are generally not suitable for weaker rock masses whilst soil classification systems (e.g. unified soil classification system) are more applicable to soils. Often, a hybrid approach must be applied to zone or domain these materials. This is discussed in Martin and Stacey (2018).

Laboratory index testing such as Atterberg limits and particle size distribution (PSD) are useful for characterising these materials as can various field index tests. Laboratory testing (direct shear and triaxial) are generally used to determine material strength parameters. Lupo et al. (2015) provides a good overview of data collection and characterisation for residual soils.

Obtaining undisturbed samples of saprolites, and residual soils in general, can be challenging and generally requires a range of approaches, such as triple tube core drilling, use of a Shelby tube or Mazier automatic core barrel for taking samples, as it permits removal of sample as it is taken from the ground, guaranteeing the 'in situ condition' of core to be sampled. If there is suitable access, collecting block samples which can be trimmed or cored in the laboratory can yield good results. Irrespective of the sampling methods, it is critical that samples are well packaged to retain moisture and keep them intact. Significant errors can occur due to poor sampling practices and incorrect packing and handling of samples; this can result in significant uncertainty related to poor testing results.

\subsection{Deriving shear strength parameters}

Slope stability analysis for saprolite slopes requires the derivation of the shear strength parameters cohesion and friction angle. These parameters can be derived using a range of methods as follows:

- Empirical look-up charts based on plasticity index derived from Atterberg limits ( $\phi$ only).

- PSD and Dhawan relationship ( $\phi$ only).

- Direct shear testing.

- Triaxial testing (typically consolidated undrained).

- Back-analysis of failures.

Lupo et al. (2015) provides a good overview and discussion of laboratory testing for the determination of shear strength properties. In this paper, it is assumed that the laboratory testing is undertaken in line with 
the practices outlined by Lupo et al. (2015). Only direct shear testing and triaxial testing can provide both cohesion and friction angle parameters. Given the difficulties associated with getting good quality samples of weak materials such as saprolites for laboratory testing, the number of tests may be limited. If back-analysis is being used, again the sample size is likely to be quite small, and generally the solution is not a unique and is typically deterministic.

When deriving shear strength parameters, it is necessary to consider uncertainty. In this case, the uncertainty could be in two forms; the first is that there is insufficient high-quality data; and secondly, natural materials have an inherent natural variability. It is important to understand both uncertainties when trying to derive reliable input parameters.

There are different ways of evaluating direct shear and triaxial laboratory test data to derive shear strength parameters. The design engineer may decide to look at all direct shear test in shear-normal plots or triaxial data in $\mathrm{P}-\mathrm{Q}$ or $\sigma_{1}-\sigma_{3}$ space and fit a curve defining mean, upper or lower bound cases. Alternatively, the design engineer may decide to compile all test data and compile statistical summaries. The approach followed is typically based on engineering judgement and personnel experience. Irrespective of what method is used to assess the laboratory results it is necessary to gain an understanding of the confidence level and natural variability of the shear strength parameters as they impact directly on the design reliability.

\subsection{Quantifying shear strength uncertainty}

The uncertainty associated with the shear strength is parameter uncertainty, and represents the spatial variability of shear strength within the soil or rock mass. Read (2013) outlined two methods that could be used for assessing parameter uncertainty. The first is the coefficient of variation $\left(C_{v}\right)$ which is determined from the mean and standard deviation (SD) of a dataset and is expressed as a percentage. Typically, a $\mathrm{C}_{\mathrm{v}}$ value of less than $10 \%$ is considered low and values greater than $30 \%$ are considered high. Read (2013) concluded that whilst $C_{v}$ is a valuable screening mechanism when making decisions about the level of confidence in a selected design parameter, it is, however, subjective and does not provide a numerical measure of the reliability of the data.

Read (2013) suggested a second approach to overcome this difficulty, based on a modified Bayesian approach (Harr 1996) to estimate the expected value of the reliability of a dataset. The method uses a simple spreadsheet format and can be applied to any set of geotechnical data. It is particularly useful for evaluating laboratory testing data. This method supplements the more common approach of using the mean, SD and median for assigning design input values into deterministic process.

The approach outlined above has been applied to triaxial testing derived shear strength data for saprolites from several sites in Ghana and Australia. This testing was undertaken under saturated conditions and is assumed to reflect the expected geotechnical conditions. This data is summarised in Tables 1, 2 and 3, and includes descriptive statistics and the lower $\left(P_{25}\right)$, median $\left(P_{50}\right)$ and upper $\left(P_{75}\right)$ quartile values. Data from Ghana covers four sites and includes information on the parent rock including granitoid (GR), meta-volcanic (MV) and graywacke (GW) rock types. The Australia data is from three sites and only one site had information available on the parent rock type.

For the Ghanaian data, separate sites are summarised as well as combining data from different sites for the same parent rock type. This marginally improved the $C_{v}$ and $E[R]$ values because of a slightly increased sample size. 
Table 1 Summary of shear strength descriptive statistics and reliability from four Ghanaian sites

\begin{tabular}{|c|c|c|c|c|c|c|c|c|c|c|}
\hline & \multicolumn{2}{|c|}{ GH-1 (GR) } & \multicolumn{2}{|c|}{ GH-2 (GR) } & \multicolumn{2}{|c|}{ GH-2 (MV) } & \multicolumn{2}{|c|}{ GH-3 (MV) } & \multicolumn{2}{|c|}{ GH-4 (GW) } \\
\hline & $c(\mathrm{kPa})$ & $\phi\left({ }^{\circ}\right)$ & $c(\mathrm{kPa})$ & $\phi\left(\left(^{\circ}\right)\right.$ & $c(\mathrm{kPa})$ & $\phi\left(1^{\circ}\right)$ & $c(\mathrm{kPa})$ & $\phi\left(\left(^{\circ}\right)\right.$ & $c(\mathrm{kPa})$ & $\phi\left(^{\circ}\right)$ \\
\hline Count & \multicolumn{2}{|c|}{4} & \multicolumn{2}{|c|}{11} & \multicolumn{2}{|c|}{7} & \multicolumn{2}{|c|}{4} & \multicolumn{2}{|c|}{7} \\
\hline Mean & 33.5 & 24.7 & 29.1 & 24.9 & 17.9 & 28.4 & 33.8 & 22.0 & 16.4 & 31.0 \\
\hline SD & 22.4 & 0.7 & 26.7 & 16.7 & 9.4 & 2.8 & 11.6 & 5.5 & 22.2 & 2.3 \\
\hline$C_{v}$ & $67 \%$ & $3 \%$ & $92 \%$ & $67 \%$ & $52 \%$ & $10 \%$ & $34 \%$ & $25 \%$ & $135 \%$ & $7 \%$ \\
\hline $\mathrm{P}_{25}$ & 24.5 & 24.3 & 18.1 & 23.3 & 12.0 & 27.4 & 27.5 & 19.5 & 0.0 & 30.0 \\
\hline$P_{50}$ & 33.3 & 24.5 & 22.0 & 24.4 & 18.6 & 28.1 & 29.0 & 22.5 & 8.0 & 31.0 \\
\hline$P_{75}$ & 42.3 & 24.8 & 34.1 & 28.1 & 23.5 & 30.5 & 35.3 & 25.0 & 27.0 & 32.5 \\
\hline Mean $E[R]$ & $50 \%$ & $33 \%$ & $38 \%$ & $46 \%$ & $56 \%$ & $44 \%$ & $33 \%$ & $50 \%$ & $33 \%$ & $56 \%$ \\
\hline $\mathrm{P}_{25} \mathrm{E}[\mathrm{R}]$ & $67 \%$ & $67 \%$ & $69 \%$ & $69 \%$ & $67 \%$ & $67 \%$ & $67 \%$ & $67 \%$ & $89 \%$ & $78 \%$ \\
\hline Mean - $0.5 \times \mathrm{SD} E[R]$ & $80 \%$ & $67 \%$ & $77 \%$ & $77 \%$ & $67 \%$ & $67 \%$ & $67 \%$ & $67 \%$ & $56 \%$ & $78 \%$ \\
\hline
\end{tabular}

Table 2 Summary of shear strength descriptive statistics and reliability for combined Ghanaian datasets

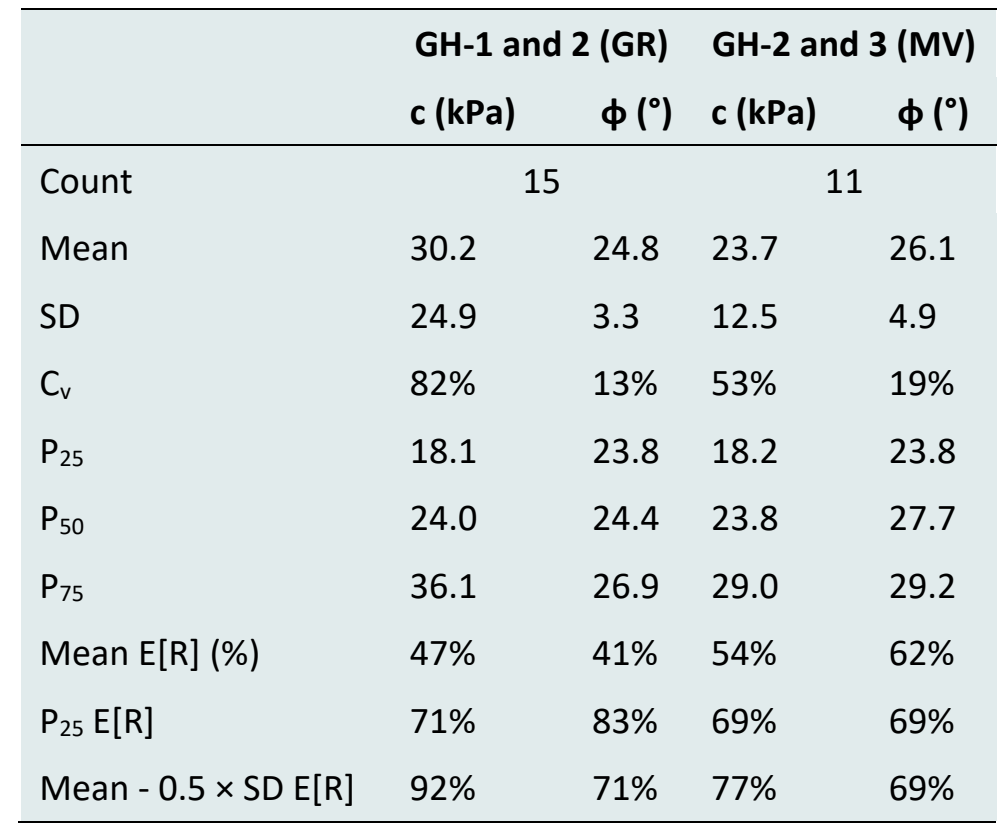


Table 3 Summary of shear strength descriptive statistics and reliability for Australian dataset

\begin{tabular}{|c|c|c|c|c|c|c|c|c|}
\hline & \multicolumn{2}{|c|}{ NSW-1 } & \multicolumn{2}{|c|}{ WA-1 (DI) } & \multicolumn{2}{|c|}{ WA-1 (AN) } & \multicolumn{2}{|c|}{ WA-2 } \\
\hline & $c(\mathrm{kPa})$ & $\phi\left(\left(^{\circ}\right)\right.$ & $c(\mathrm{kPa})$ & $\phi\left({ }^{\circ}\right)$ & c (kPa) & $\phi\left(1^{\circ}\right)$ & c (kPa) & $\phi\left(^{\circ}\right)$ \\
\hline Count & \multicolumn{2}{|c|}{39} & \multicolumn{2}{|c|}{18} & \multicolumn{2}{|c|}{5} & \multicolumn{2}{|c|}{5} \\
\hline Mean & 26.4 & 27.1 & 35.6 & 25.1 & 18.7 & 25.0 & 21.4 & 38.7 \\
\hline SD & 27.8 & 6.6 & 23.5 & 3.8 & 15.1 & 1.2 & 11.4 & 7.1 \\
\hline $\mathrm{C}_{\mathrm{v}}$ & $105 \%$ & $24 \%$ & $66 \%$ & $15 \%$ & $81 \%$ & $5 \%$ & $53 \%$ & $18 \%$ \\
\hline $\mathrm{P}_{25}$ & 9.0 & 23.0 & 18.6 & 23.7 & 3.8 & 26.2 & 9.5 & 34.2 \\
\hline$P_{50}$ & 18.0 & 27.6 & 26.5 & 24.7 & 24.3 & 26.4 & 27.2 & 43.3 \\
\hline$P_{75}$ & 29.3 & 32.5 & 48.0 & 27.8 & 27.5 & 27.0 & 28.6 & 43.5 \\
\hline Mean $E[R]$ & $29 \%$ & $54 \%$ & $32 \%$ & $45 \%$ & $57 \%$ & $43 \%$ & $57 \%$ & $57 \%$ \\
\hline P25 E[R] & $29 \%$ & $71 \%$ & $88 \%$ & $70 \%$ & $71 \%$ & $43 \%$ & $71 \%$ & $71 \%$ \\
\hline Mean $-0.5 \times$ SD E[R] & $59 \%$ & $71 \%$ & $55 \%$ & $75 \%$ & $57 \%$ & $71 \%$ & $86 \%$ & $86 \%$ \\
\hline
\end{tabular}

Generally, it is observed the there is a lower $C_{v}$ and higher $E[R]$ across both the Australian and Ghanaian datasets for friction angle and this parameter is generally more reliable. Both datasets indicate the $E[R]$ of the mean value is below what is outlined in Read (2009) for feasibility and implementation levels. For $P_{25}$ or mean $-0.5 \times$ SD values, the $E[R]$ is within the ranges outlined by Read and Stacey (2009). Jefferies et al. (2008) and Renani et al. (2018) discuss how choosing material inputs can influence the FS and PF of a slope. From this it can be inferred that using mean values does not adequately reflect natural variability within soil or rock mass. It is also generally known that slopes rarely fail at their average strength, thus it would be more suitable to use a lower value if a more reliable design is required. Based on the data summarised in this paper it is concluded that using $\mathrm{P}_{25}$ or mean $-0.5 \times$ SD provides inputs that are more in line with the target confidence levels outlined by Read (2009). An alternative would be to undertake probabilistic design analyses.

\subsection{Shear strength and saprolite slope design parameters}

Figure 6 is a scatter plot of design cohesion versus friction angle from various sites in Australia, Africa, Madagascar and Suriname (Abrahams et al. 2015); the data is presented in this way to demonstrate the range of values for the datasets considered. Generally, the cohesion and friction angle form a cluster in the $10-35 \mathrm{kPa}$ and $25-35^{\circ}$ range respectively. After removing cohesion outliers ( 150 and $500 \mathrm{kPa}$ ), the mean and SD for cohesion and friction angle are $22.5 \pm 10.4 \mathrm{kPa}$ and $28.4 \pm 4.4^{\circ}$, respectively. 


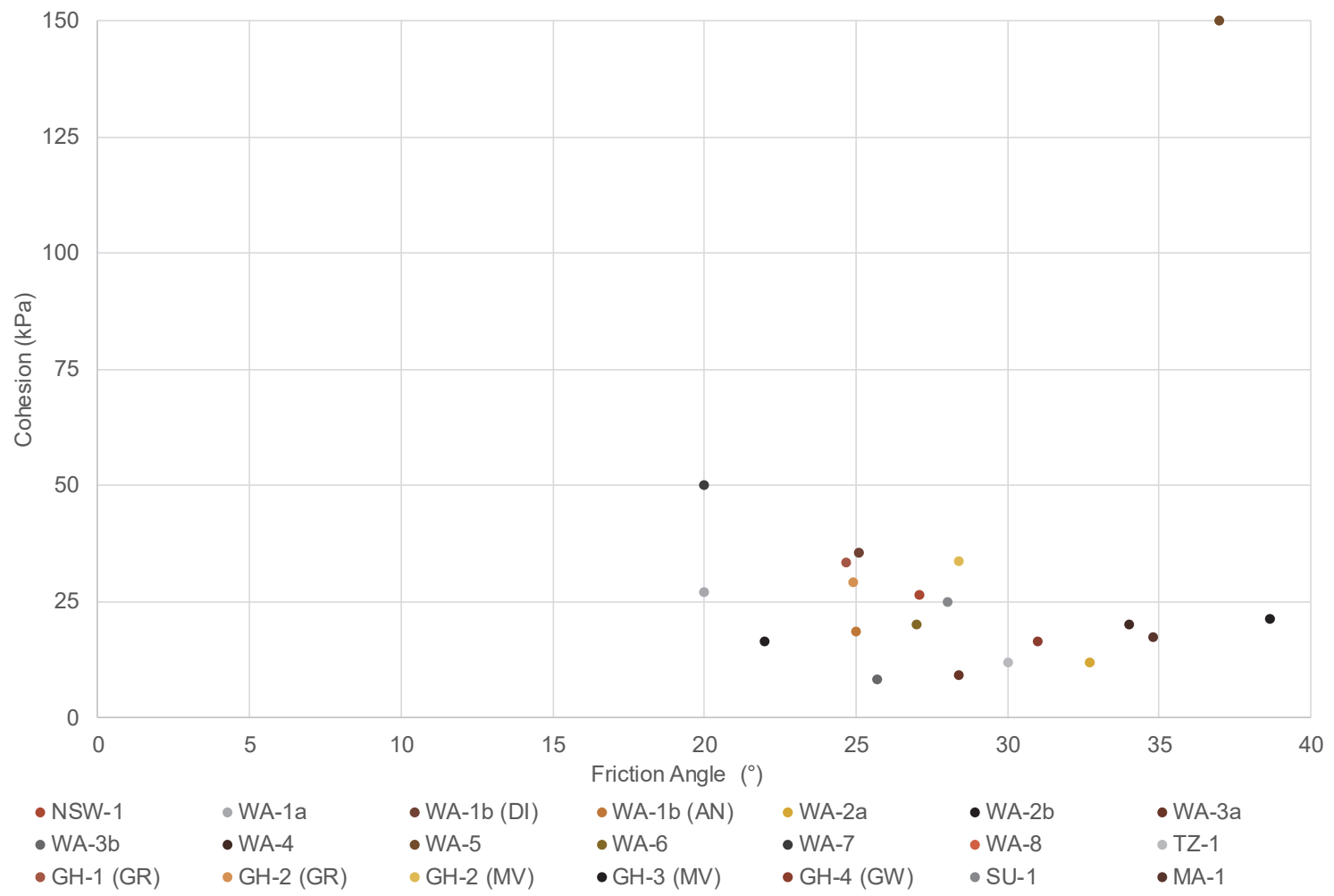

Figure 6 Saprolite scatter plot for cohesion and friction angle for various sites

Table 4 is a summary of the shear strength parameters and the slope design parameters from various mine sites. Using a generic saprolite based on the properties shown in Table 4, simple empirical stability analyses were done using the method described by Carranza-Torres and Hormazabal (2018) to demonstrate the impact of choosing different material inputs. A slope height of $50 \mathrm{~m}$ at an inter-ramp angle (IRA) of $30^{\circ}$ under dry conditions (i.e. no active phreatic surface) was assumed. Relict structure and matric suction have not been included in this example. It is possible to include these; however, this would require a more-sophisticated analysis method. The important thing is to consider uncertainty in the analysis, whether that be for shear strength of the material mass under different groundwater conditions or the shear strength of a relict structure.

For this example, it is noted that mean case provides a higher FS; typically, this would be optimised to an IRA of $34.5^{\circ}$ to satisfy a FS of 1.2; using mean - $0.5 \times$ SD input values, results in a FS of 1.19 whilst using a $P_{25}$ value would require flattening the slope to an IRA of $28.5^{\circ}$. It would be expected that the FS derived using lower input values with a higher reliability, would have a lower PF and a higher design reliability. Understanding the impact of uncertainty on the slope design will contribute to more meaningful assessment of risk. 
Table 4 Summary of saprolite shear strength and slope design parameters

\begin{tabular}{|c|c|c|c|c|c|c|}
\hline Site & $c(\mathrm{kPa})$ & $\phi\left({ }^{\circ}\right)$ & $\mathrm{BH}(\mathrm{m})$ & BFA $\left({ }^{\circ}\right)$ & BW (m) & $\operatorname{IRA}\left({ }^{\circ}\right)$ \\
\hline NSW-1 & 26.4 & 27.1 & 9 & 45 & 10 & 25 \\
\hline WA-1a & 20.0 & 27.0 & & & & \\
\hline WA-1b (DI) & 35.6 & 25.1 & 12 & 50 & 11 & 30 \\
\hline WA-1b (AN) & 18.7 & 25 & & & & \\
\hline WA-2a & 12.0 & 32.7 & 10 & 50 & 6 & 35 \\
\hline WA- $2 b$ & 21.4 & 38.7 & & & & \\
\hline WA-3a & 9.3 & 28.4 & 10 & 47.5 & 3.5 & 38 \\
\hline WA-3b & 8.3 & 25.7 & 10 & 48 & 4.9 & 36 \\
\hline WA-4 & 20.0 & 34.0 & $6-8$ & 60 & & $26-35$ \\
\hline WA-5 & 150.0 & 37.0 & - & - & - & - \\
\hline WA-6 & 20.0 & 27.0 & $5-7$ & $50-70$ & - & 32 \\
\hline WA-7 & 50.0 & 20.0 & 20 & 50 & 10 & 37 \\
\hline WA-8 & 500.0 & 25.0 & 10 & $35-55$ & & $25-30$ \\
\hline TZ-1 & 12.0 & 30.0 & 5 & 60 & 3.5 & 38 \\
\hline GH-1 (GR) & 33.5 & 24.7 & 8 & 45 & 9.2 & 25 \\
\hline $\mathrm{GH}-2$ (GR) & 29.1 & 24.9 & $6 \& 12$ & 65 & $6 \& 12$ & $34 \& 44$ \\
\hline GH-2 (MV) & 17.9 & 28.4 & & & & \\
\hline GH-3 (MV) & 33.8 & 22.0 & 6 & 65 & 6 & 34 \\
\hline GH-4 (GW) & 16.4 & 31.0 & 16 & 45 & 10 & 32 \\
\hline SU-1 & 25.0 & 28.0 & 8 & 60 & 8 & 32 \\
\hline MA-1 & 17.4 & 34.8 & 8 & 45 & 4 & 34 \\
\hline Mean & 22.5 & 28.4 & \multirow{2}{*}{\multicolumn{4}{|c|}{$\mathrm{FS}=1.37 ;$ optimised IRA $=34.5^{\circ}$}} \\
\hline SD & 10.4 & 4.8 & & & & \\
\hline $\mathrm{P}_{25}$ & 16.9 & 25 & \multicolumn{4}{|c|}{$\mathrm{FS}=1.14$; decrease $\mathrm{IRA}$ to $28.5^{\circ}$ for $\mathrm{FS}=1.2$} \\
\hline Mean $-0.5 \times$ SD & 12.0 & 23.6 & \multicolumn{4}{|c|}{$\mathrm{FS}=1.19$} \\
\hline
\end{tabular}

Note: $\mathrm{BH}=$ bench height; $\mathrm{BFA}=$ batter face angle; $\mathrm{BW}=$ bench width; IRA = inter-ramp angle

\section{Conclusion}

This paper presents an overview of some issues associated with slope design in residual soils, including discussion on how uncertainty can impact on the slope design. Using saprolite data from several mine sites in Australia, Africa, Suriname and Madagascar an attempt is made to quantify the uncertainty associated with shear strength parameters commonly used as inputs into slope stability analyses for saprolites. It was found that mean values derived from laboratory testing data generally do not meet the target confidence levels for feasibility and implementation as defined by Read (2009). Using a lower value, such as the $P_{25}$ or mean $-0.5 \times S D$, is generally much closer to the target confidence levels for the data presented in this paper. This may be different for dry conditions when matric suction is considered. 
Shear strength data and slope design parameters for saprolites from several mine sites is presented within this paper, and it is hoped that it will be of some value to geotechnical engineers practicing in open pit mining.

The impact of uncertainty has been demonstrated using a simple example. Using higher confidence and thus more-reliable shear strength inputs will result in improved design reliability, but can result in flatter slopes. Ultimately, the risk profile is a decision that needs to be made by the slope owner.

\section{References}

Abrahams, G, Raynor, M \& Mandisodza, K 2015, 'Saprolite Slope Design at the Rosebel Gold Mine', Proceedings of the 2015 International Symposium on Slope Stability in Open Pit Mining and Civil Engineering, The South African Institute of Mining and Metallurgy, Johannesburg, pp. 753-768.

Anderson, MG \& Lloyd, DM 1991, 'Using a combined slope hydrology-stability model to develop cut slope design charts', Proceedings of the Institute of Civil Engineers, vol. 91, issue 4, part 2.

Aydin, A 2006, 'Stability of saprolitic slopes: nature and role of field scale heterogeneities', Natural Hazards and Earth System Sciences, vol. 6, pp. 89-96.

Aydin, A \& Duzgoren-Aydin, NS 2002, 'Indices in scaling and predicting weathering-induced changes in rock properties', Environmental and Engineering Geoscience, vol. 8, issue 2, pp. 121-135.

Aydin, A, Duzgoren-Aydin, NS \& Malpas, JG 2000, 'A review of igneous and metamorphic saprolites', Journal of Nepal Geological Society, vol. 22, pp. 11-16.

Bell, FG 2000, Engineering Properties of Soils and Rocks, 4th edn, Blackwell Science, Oxford.

Bieniawski, ZT 1989, Engineering Rock Mass Classifications, John Wiley \& Sons, New York.

Bland, W \& Rolls, D 1998, Weathering: An Introduction to Scientific Principles, Hodder Education.

Blight, GE 1985, 'Residual soils in South Africa', in EW Brand \& HB Phillipson (eds.), Sampling and Testing of Residual Soils, A Review of International Practice Technical Committee on Sampling and Testing of Residual Soils, Scorpion Press, Hong Kong, pp. 159-168.

Blight, GE 1997, Mechanics of Residual Soils, A.A. Balkema, Rotterdam.

Brand, EW 1984, 'Landslides in Southeast Asia: a state-of-the-art report', Proceedings of the 4th International Symposium on Landslides, addendum 3, Canadian Geotechnical Society, Richmond, pp. 105-106.

Brand, EW, Dale, M \& Nash, JM 1986,'Soil pipes and slope stability in Hong Kong', Quarterly Journal of Engineering Geology and Hydrology, vol. 19, no. 3, pp. 301-303.

Brand, EW \& Phillipson, HB 1985, 'Sampling and testing of residual soils: a review of international practice', The International Society for Soil Mechanics and Foundation Engineering, Scorpion Press, Hong Kong, pp. 194.

Burton, BT 1998, Earthworks with Wet, Fine-grained Tropical Residual Soils, unpublished Master of Engineering report, University of Alberta, Edmonton.

Carranza-Torres, C \& Hormazabal, E 2018, 'Computational tools for determination of factor of safety and location of the critical circular failure surface for slopes in Mohr-Coulomb dry ground', Proceedings of Slope Stability 2018, Asociacion Nacional de Ingenieros de Minas and Colegio Oficial de Ingenieros de Minas del Sur, Seville.

Chigira, M, 2001, 'Micro-sheeting of granite and its relationship with landsliding specifically after the heavy rainstorm in June 1999, Hiroshima Prefecture, Japan', Engineering Geology, vol. 59, pp. 219-231.

Ching, RKH, Sweeney DJ \& Fredlund, DG 1984, 'Increase in factor of safety due to soil suction for two Hong Kong slopes', Proceedings of the 4th International Symposium on Landslides, Canadian Geotechnical Society, Richmond, pp. 617-623

Costa, AJ \& Fernandes, CEM 1985, 'Slides in saprolites from gneissic rocks with relict slip surfaces: the B.N.E.D.E.S. case study', Proceedings of the First International Conference on Geomechanics in Tropical Lateritic and Saprolitic Soils, Brazilian Society for Soil Mechanics, Brasilia, pp. 49-55.

Cowland, JW \& Carbray, AM 1988, 'Three cut slope failures on relict discontinuities in saprolitic soils', Proceedings of the 2nd International Conference on Geomechanics in Tropical Soils, A.A. Balkema, Rotterdam, pp. 253-258.

Deere, DU \& Patton, FD 1971, 'Slope stability in residual soils', Proceedings of the Fourth Pan American Conference on Soil Mechanics and Foundation Engineering, vol. 1, American Society of Civil Engineers, Reston, pp. 87-170.

De Mello, VFB 1972, 'Thoughts on soil engineering applicable to residual soils', Proceedings of the 3rd South-East Asian Conference on Soil Engineering, Southeast Asian Society of Soil Engineering, Hong Kong, pp. 5-43.

Drumright, EE 1989, The Contribution of Matric Suction to the Shear Strength of Unsaturated Soils, PhD thesis, Colorado State University, Fort Collins.

Dunn, MJ 2014, 'Geotechnical models and data confidence in mining geotechnical design', Proceedings of the Third Australasian Ground Control in Mining Conference, The Australasian Institute of Mining and Metallurgy, Melbourne, pp. 127-133.

Dunn, MJ 2015, 'How reliable are your design inputs?' in Y Potvin (ed.), Proceedings of the International Seminar on Design Methods in Underground Mining, Australian Centre for Geomechanics, Perth, pp. 367-381.

Escario, V \& Saez, J 1986, 'The shear strength of partly saturated soils', Géotechnique, vol. 36, issue 3, pp. 453-456.

Fredlund, DG, \& Rahardjo, H, 1985, 'Theoretical context for understanding unsaturated residual soil behavior', Proceedings of the 1st International Conference on Geomechanics in Tropical Lateritic and Saprolitic Soils, vol. 1, Brazilian Society for Soil Mechanics, Brasilia, pp. 295-305.

Fredlund, DG \& Rahardjo, H 1993, Soil Mechanics for Unsaturated Soils, John Wiley \& Sons, New York. 
Fredlund, DG, \& Rahardjo, H 1994, 'Hillside slope stability assessment in unsaturated residual soils', Proceedings of the IKRAM Seminar on Geotechnical Aspects of Hillside Development.

Fredlund, DG, Morgenstern, NR \& Widger, RA, 1978, 'The shear strength of unsaturated soils', Canadian Geotechnical Journal, vol. 15, pp. 313-321.

Gan, JKM \& Fredlund, DG 1988, 'Multistage direct shear testing of unsaturated soils', Geotechnical Testing Journal, vol. 11, issue 2, pp. 132-138.

Gan, JKM, \& Fredlund, DG 1992, Direct Shear Testing of a Hong Kong Soil Under Various Applied Matric Suctions, GEO Report No. 11, Geotechnical Engineering Office, Hong Kong,

Griffith, DV \& Lu, N 2005, 'Unsaturated slope stability analysis with steady infiltration or evaporation using elasto-plastic finite elements, International Journal for Numerical and Analytical Methods in Geomechanics, vol. 29, issue 3, pp. $249-267$.

Harr, ME 1996, Reliability-based Design in Civil Engineering, McGraw-Hill, Dover.

Hencher, SR \& Martin, RP 1982, 'The description and classification of weathered rocks in Hong Kong for engineering purposes', Proceedings of the Seventh South-East Asian Geotechnical Conference, Southeast Asian Geotechnical Society, Bangkok, pp. 125-142.

Hencher, SR \& McNicholl, DP 1995, 'Engineering in weathered rock', Quarterly Journal Engineering Geology, vol. 28, pp. 253-266.

Hencher, SR, Massey, JB \& Brand, EW 1984, 'Application of back-analysis to some Hong Kong landslides', Proceedings of the 4th International Symposium on Landslides, Canadian Geotechnical Society, Richmond, pp. 631-638.

Horn, HM \& Deere, DU 1962, 'Frictional characteristics of minerals', Géotechnique, vol. 12, issue 4, pp. 319-335.

Irfan, TY 1998, 'Structurally controlled landslides in saprolitic soils in Hong Kong', Geotechnical and Geological Engineering, vol. 16, issue 3, pp. 215-238.

Irfan, TY 1994, 'Mechanism of creep in a volcanic saprolite', Quarterly Journal of Engineering Geology and Hydrogeology, vol. 27, issue 3, pp. 211-230.

Irfan, TY \& Woods, NW 1988, 'The influence of relict discontinuities on slope stability in saprolitic soil', Proceedings of the 2nd International Conference on Geomechanics in Tropical Soils, A.A. Balkema, Rotterdam, pp. 253-258.

Jefferies, M, Lorig, L \& Alvarez, C 2008, 'Influence of rock strength spatial variability on slope stability', Proceedings of the First International FLAC/DEM Symposium on Numerical Modelling, Itasca Consulting Group, Inc., Minneapolis.

Lindquist, ES \& Goodman, RE 1994, 'Strength and deformation properties of a physical model melange', Proceedings of the 1st North American Symposium, Rock Mechanics: Models and Measurements Challenges from Industry, A.A. Balkema, Rotterdam, pp. 843-850.

Lu, N \& Godt, J 2008, 'Infinite slope stability under steady unsaturated seepage conditions', Water Resources Research, vol. 44, issue 11.

Lu, N \& Likos, WJ 2004, Unsaturated Soil Mechanics, Wiley, Hoboken.

Lumb, P 1975, 'Slope failures in Hong Kong', Quarterly Journal of Engineering Geology and Hydrogeology, vol. 8, pp. 31-65.

Lupo, J, Byers, T \& Brunhart-Lupo, M 2015, 'Pit slope design challenges in residual soils and highly weathered rock', Proceedings of the 2015 International Symposium on Slope Stability in Open Pit Mining and Civil Engineering, The South African Institute of Mining and Metallurgy, Johannesburg, pp. 697-712.

Marinos, P \& Hoek, E 2000, 'GSI: a geologically friendly tool for rock mass strength estimation', Proceedings of GeoEng 2000: an International Conference on Geotechnical \& Geological Engineering, Technomic Publishing Company, Lancaster, pp. 1422-1442.

Martin, D \& Stacey, P 2018, Guidelines for Open Pit Slope Design in Weak Rocks, CSIRO Publishing, Collingwood.

Massad, F \& Teixeira, HR 1985, 'Deep cut on saprolitic soils conditioned by relict structures', Proceedings of the First International Conference on Geomechanics in Tropical Lateritic and Saprolitic Soils, Brazilian Society for Soil Mechanics, Brasilia, pp. 381-391.

Massey, JB, Irfan, TY \& Cipullo, A 1989, 'The characterisation of granitic saprolitic soils', Proceedings of the 12th International Conference on Soil Mechanics and Foundation Engineering, vol. 1, Taylor \& Francis, Milton Park, pp. 533-542.

McCarthy, DF 1993, Essentials of Soil Mechanics: Basic Geotechnics, 5th edition, Prentice-Hall International, Englewood Cliffs.

Newcomen, WH, Burton, BT \& Geyer, J 2000, 'Pit slope design challenges in residual soils and weathered rock: background and a case study', Proceedings of the SME Annual Meeting, Society for Mining, Metallurgy \& Exploration, Englewood.

Patton, FD \& Deere, DU 1971, 'Geologic factors controlling slope stability in open pit mines,' in C Brawner \& V Miligan (eds), Proceedings of the First International Conference on Stability, American Institute of Mining, Metallurgical and Petroleum Engineers, New York, pp. 23-47.

Press, F \& Siever, R 1994, Understanding Earth, Freeman WH \& Co Ltd, New York.

Rahardjo, H, Lim, T, Chang, M \& Fredlund, D 1995, 'Shear-strength characteristics of a residual soil', Canadian Geotechnical Journal, vol. 32, no. 1, pp. 60-77.

Read, J 2009, 'Data uncertainty', in J Read \& P Stacey (eds), Guidelines for Open Pit Slope Design, CSIRO Publishing, Collingwood, pp. 213-220.

Read, J 2013, 'Data gathering, interpretation, reliability and geotechnical models', in P Dight (ed.), Proceedings of the 2013 International Symposium on Slope Stability in Open Pit Mining and Civil Engineering, Australian Centre for Geomechanics, Perth, pp. 81-90.

Read, J \& Stacey, P 2009, Guidelines for Open Pit Slope Design, CSIRO Publishing, Collingwood.

Renani, HR, Martin, CD, Verona, P \& Lorig, L 2018, 'Probabilistic stability analysis of slopes in highly heterogeneous rock masses', Proceedings of Slope Stability 2018, Asociacion Nacional de Ingenieros de Minas and Colegio Oficial de Ingenieros de Minas del Sur, Seville. 
Rezaur, RB, Rahardjo, H, Leong, EC, \& Lee, TT 2003, 'Hydrologic behavior of residual soil slopes in Singapore', Journal of Hydrologic Engineering, vol. 8, no. 3, pp. 133-144.

Satija, BS 1978, Shear Behaviour of Partially Saturated Soils, PhD thesis, Indian Institute of Technology, New Delhi.

Schellmann, W 2008, An Introduction in Laterite: Products and Processes of Intensive Rock Weathering, viewed 23 October 2018, http://www.laterite.de/index.html

Sowers, GF 1985, Residual Soils in the United States, in Sampling and Testing of Residual Soils: A Review of International Practice, in EW Brand \& HB Phillipson (eds.), Scorpion Press, Hong Kong, pp. 183-191.

St John, BJ, Sowers, GF \& Weaver, CE 1969, 'Slickensides in residual soils and their engineering significance', Proceedings of the 7th International Conference Soil Mechanics and Foundation Engineering, vol. 2, Sociedad Mexicana de Mecanica, Mexico City, pp. 591-597.

Terzaghi, K 1936, 'The shearing resistance of saturated soils and the angle between the planes of shear', Proceedings First International Conference on soil Mechanics, vol. 1, pp. 54-59.

The Geological Society 1990, 'Tropical residual soils: A Geological Society Engineering Group Working Party report', Quarterly Journal Engineering Geology and Hydrogeology, vol. 23, issue 1, pp. 4-101.

Toll, DG 1990, 'A framework for unsaturated soil behaviour', Geotechnique, vol. 40, no. 1, pp. 31-44.

Vargas, M \& Pichler, E 1957, 'Residual soil and rock slides', Proceedings of the Fourth International Conference on Soil Mechanics and Foundation Engineering, Butterworths Scientific Publications, London, pp. 394-398.

Vargas JE, Oliveira, ARB, Costa Filho, LM \& Campos, TP 1986, 'A study of the relationship between the stability of slopes in residual soils and rain intensity', Proceedings of the International Symposium on Environmental Geotechnology, Envo Publishing, Leigh, pp. 491-500.

Wen, BP \& Aydin, A 2003, 'Microstructural study of a natural slip zone, quantification and deformation history', Engineering Geology, vol. 68, pp. 289-317.

Wesley, LD 2010a, Fundamentals of Soil Mechanics for Sedimentary and Residual Soils, John Wiley \& Sons Ltd, New York.

Wesley, LD 2011, 'Stability of slopes in residual soils', Obras y Proyectos, no. 10, pp. 47-61.

Wesley, LD 2013, 'Residual soils and the teaching of soil mechanics', in P Delage, J Desrues, R Frank, A Puech \& F Schlosser (eds), Proceedings of the 18th International Conference on Soil Mechanics and Geotechnical Engineering, Presses des Pontes, France, pp. 3481-3482.

West, L, Hencher, SR, \& Cousens, TW 1991, 'Assessing the stability of slopes in heterogeneous soils', in DH Bell (ed.), Proceedings of the 6th International Symposiums on Landslides, A.A. Balkema, Rotterdam, pp. 591-595.

Wilkinson, PL, Anderson, MG \& Lloyd, DM, 2002, 'An integrated hydrological model for rain-induced landslide prediction', Earth Surface Processes and Landforms: The Journal of the British Geomorphological Research Group, vol. 27, no. 12, pp. 1285-1297. 